\title{
RELATIONSHIP BETWEEN FUNCTIONAL MOVEMENT SCREEN AND ATHLETIC PERFORMANCE IN YOUNG SOCCER PLAYERS ${ }^{1}$
}

\section{ALTYAPI FUTBOLCULARINDA FONKSIYONEL HAREKET ANALIZININ ATLETIK PERFORMANSLA ILIŞKISII}

\author{
Mustafa ŞAHIN ${ }^{1}$, Ogulcan DOĞANAY ${ }^{2}$, Bülent BAYRAKTAR ${ }^{3}$ \\ 1-2istanbul University, Faculty of Sport Sciences, Department of Coaching Education, İstanbul / Turkey \\ ${ }^{3}$ İstanbul University, Faculty of Medicine, Internal Medicine, Sports Medicine Department, İstanbul / Turkey
}

ORCID ID: 0000-0002-6879-44981 ${ }^{1}, 0000-0003-4267-91652^{2}, 0000-0001-8102-48963^{3}$

Öz: Amaç: Bu çalışma altyapı futbolcularının fonksiyonel hareket taraması (FMS) skorlarının analizi ve performansla olan ilişkisini belirlemek amacıyla yapılmıștır. Yöntem: Çalışma farklı kulüplerin 14-16 yaş aralığında oynayan toplam 92 futbolcu ile gerçekleştirilmiş̧ir. Araştırmada futbolcuların yaş, boy uzunluğu, vücut ağırlığı, Beden Kütle indeksi (BKI), Uzun atlama, Dayanıklılık, Çeviklik, $10-20$ ve $30 \mathrm{~m}$. Sürat ile FMS bilessenleri incelenmiștir. Calışmanın istatistiksel analizi SPSS 21.0 programı ile yapılmış, gruplara arası karşılaştırmalar bağımsız t-testi ile, FMS skorları ile performans ilişkisi Pearson korelasyon analizi ile gerçekleștirilmiștir. Bulgular: Futbolcuların toplam FMS puan ortalaması 14,40 olarak tespit edilmiştir. FMS testinde skorların en az birinde asimetrisi olan sporcuların oranının \%61.96 olduğu, \%38,04 futbolcunun ise asimetrisinin olmadığı görülmüștür. FMS skorları ile performans parametreleri arasındaki ilișki incelendiğinde Dayanıklılık ile Active straigth leg raise $(\mathrm{r}=0,270)$ ve rotary stability $(r=0,259)$ arasında $\mathrm{p}<0,05$ düzeyinde ilişki pozitif iliski olduğu tespit edilmiștir. Ceviklik testi ile active straigth legraise arasında $\mathrm{p}<0,05$ düzeyinde negatif ilişki $(\mathrm{r}=-0,273)$ bulunmuştur. Sonuç: Altyapı futbolcularında FMS skorlarının normal olduğu, fakat sağ ve sol taraf asimetri yaygınlığı açısından önemli problemlerin bulunduğu söylenebilir. Alt yapı futbolcularında Fonksiyonel hareket değerlerinin dayanıklılık ve çeviklik özelliği ile ilişkisi bulunmaktadır.

Anahtar Kelimeler: Futbol, Hareket Analizi, FMS, Atletik Performans, Yaralanmaların Önlenmesi
Abstract: Aim: This study was conducted to determine the relationship between the analysis of functional movement screen (FMS) scores and the performance of young soccer players. Method: The study was conducted with a total of 92 soccer players playing at different clubs aged between 1416. In the study, FMS components were examined with age, height, body weight, body mass index (BMI), long jump, endurance, agility, and a 10-m, 20-m, and 30-m sprint test. Statistical analysis of the study was conducted using the SPSS 21.0 program. Comparisons between groups were made using the independent t-test. The FMS scores and performance relationship were analyzed using Pearson's correlation analysis. Finding: The total FMS score of the soccer players was determined as 14.40 . In the FMS test, $61.96 \%$ of the soccer players had at least one asymmetry; $38.04 \%$ of the soccer players had no asymmetry. When the relationship between FMS scores and performance parameters was examined, it was determined that there was a positive correlation between endurance and active straight leg raise $(r=0.270)$ and rotary stability $(r=0.259)$. A negative correlation $(\mathrm{r}=-0.273)$ was found between the agility test and active straight leg raise at $p<0.05$. Conclusion: It can be said that FMS scores are normal in infrastructural soccer players, but there are significant problems in terms of the excess of asymmetry in the right and left sides. In young soccer players, functional movement scores are related to endurance and agility.

Key Words: Soccer, Movement Analysis, FMS, Athletic Performance, Injury Prevention

Doi: 10.17363/SSTB.2018.1.1

(1) Corresponding Author: Mustafa ŞAHIN, İstanbul University, Faculty of Sport Sciences, Department of Coaching Education, İstanbul/Turkey, msahin@istanbul.edu.tr, Received: 13.11.2017, Accepted: 11.04.2018, Type ofarticle (Research -Application) Conflict of Interest: None / "None of Ethics Committee" 


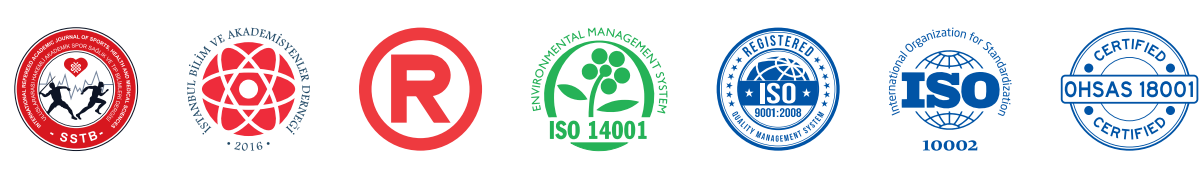

SSTB

www.sstbdergisi.com

International Refereed Academic Journal of Sports, Health and Medical Sciences

January - February - March Issue 26 Winter Year: 2018 ID:370 K:424

ISSN Print: 2146-8508 Online 2147-1711

(ISO 18001-OH-0090-13001706 / ISO 14001-EM-0090-13001706 / ISO 9001-QM-0090-13001706 / ISO 10002-CM-0090-13001706)

(TRADEMARK)

(2015/04315- 2015-GE-18972)

\section{INTRODUCTION}

Functional movement screen (FMS), which is a reliable method for evaluating the movement of athletes (Moran et al., 2016:527-536; Kiesel et al., 2007:147-158), is a detailed evaluation method of human movement which consists of 7 movement tests and 3 clearing movements (Cook et al., 2014:396-409). FMS was first applied to American football players and then research spread rapidly (Agresta et al., 2014: 1203-1207; Bardenett et al., 2015:303-308; Li et al., 2015:1166; Warren et al., 2015:163). The movement screen test, which is used to evaluate mobilization and stabilization, has been applied in many countries and areas (Bodden et al., 2013:219-225; Loudon et al., 2014:909-913; Parenteau et al., 2014:169-175; Kazman et al., 2014:672-678; Schneiders et al., 2011:75-82; Teyhen et al., 2014:413-420).

The interest of sport experts for corrective exercises to increase the range of motion of athletes has begun to increase day by day. FMS is a method in which each movement score is assessed within itself, as well as with 7 different measurements that are evaluated in asymmetry and total score, and corrective exercises can be given according to the results (Mokha et al., 2016:276-282;). If the total of the 7 measurements is below 14 points, it increases the risk of injuries (Chorba., 2010:4754). It is emphasized that work is also impor- tant for young athletes in the system, which is mostly performed on adults (Marques., 2017:977-985).

When evaluating physical performance, shuttles, push-ups, endurance, sprints, jumps, agility and strength tests are usually applied (Meeuwisse and Fowler, 1988: 35-42). The main goal of pre-season tests is to reduce the risk factors that may cause injuries, to prevent the recurrence of injuries, to improve performance, and to improve the quality of life. Surveys have shown that performance tests or fitness tests are uncertain to meet these goals (Metzl., 2000: 577-592).

The purpose of this study is to provide a detailed explanation of the results of FMS in young soccer players.

When we looked at the research on youth soccer, we found many conditioning studies but very few studies on movement analysis.

With this approach, we researched whether athletic performance characteristics were affected by FMS total score, individual scores, and asymmetry, in order to have knowledge about the relationship between movement analysis and the performance components of young soccer players.

\section{METHODS}

This research was conducted with a total of 92 soccer players who studied at the Turkish 


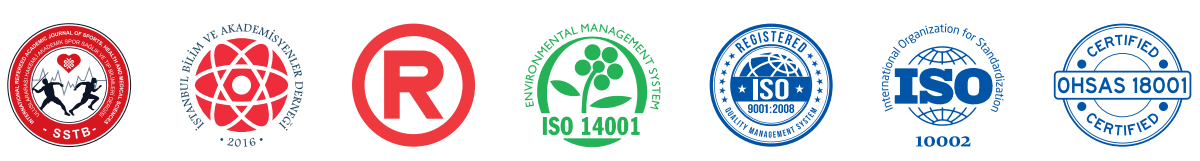

SSTB

www.sstbdergisi.com

International Refereed Academic Journal of Sports, Health and Medical Sciences

January - February - March Issue 26 Winter Year: 2018 ID:370 K:424

ISSN Print: 2146-8508 Online 2147-1711

(ISO 18001-OH-0090-13001706 / ISO 14001-EM-0090-13001706 / ISO 9001-QM-0090-13001706 / ISO 10002-CM-0090-13001706)

(TRADEMARK)

(2015/04315- 2015-GE-18972)

Football Federation Meral Celal Aras Sports High School and played at different youth soccer clubs.

The age, height, body weight, body mass index (BMI), long jump, endurance, agility, speed, and FMS evaluations of the soccer players were examined in the research.

In our study, we used the New Test-Powertimer 300 test system (Enoksen et al., 2009: 77-84), traffic cones, disc cones, a speaker, stadiometer, and a Tanita BC418 segmental body composition device (Tanita, Japan). The FMS kit was used for functional movement screen.

Height: The heights of the soccer players were determined by measuring the distance between the head and foot. The results are reported in centimeters (Table 1).

Body Weight: Body weight measurements were made with the Tanita BC418 body composition device; the soccer players were measured without shoes with standard sportswear (shorts, t-shirts). The results were recorded in kilograms.

Body Mass Index: BMI was calculated with using the formula weight $/$ height $^{2}\left(\mathrm{~kg} / \mathrm{m}^{2}\right)$.

The FMS test was applied to the athletes first, and performance tests were applied 1 day after. The athletes were prepared for performance tests with a 20-minute coordination- based warm-up. Five minutes rest was given between the tests.

Standing long jump: This was measured using a steel meter on a non-slip floor. The measurement was made by measuring the distance between the starting point and the heel of the soccer player at the place where they fell.

During the test, the arms of the soccer players had to be behind their body, the knees had to be bent and the body leaning slightly forward. The best score of three trials was recorded (Reiman and Manske, 2009:193-201).

Agility: The pro-agility test was performed. Photocell (Newtest Powertimer 300) was used to measure the duration. In the test, a single photocell was used. The athlete started the test by running to the right from the midpoint of the 10-meter field, then to the left, and again to the starting point to end the test. The same procedure was repeated by starting to the left and the best time was recorded in seconds (Harman and Garhammer, 2008: 249-292).

Speed: The athlete started the test with a command from the test manager from the starting line, which was $50 \mathrm{~cm}$ behind the starting photocell. The measurements were made with photocells located at 10-20 and 30th meters of the 30-m running distance. Two measurements were taken and five minutes of rest 


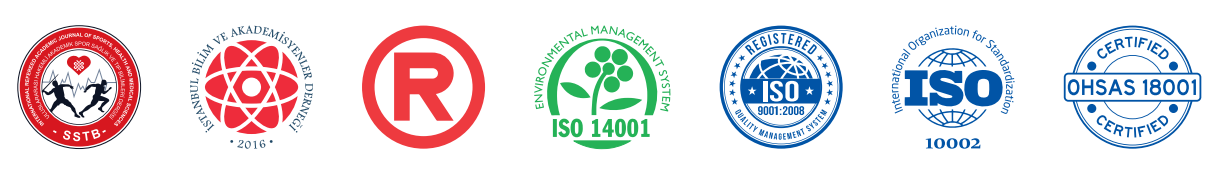

SSTB

www.sstbdergisi.com

International Refereed Academic Journal of Sports, Health and Medical Sciences

January - February - March Issue 26 Winter Year: 2018 ID:370 K:424

ISSN Print: 2146-8508 Online 2147-1711

(ISO 18001-OH-0090-13001706 / ISO 14001-EM-0090-13001706 / ISO 9001-QM-0090-13001706 / ISO 10002-CM-0090-13001706)

(TRADEMARK)

(2015/04315- 2015-GE-18972)

was given between the two measurements. The best time was recorded.

Endurance: Endurance was determined by using the Yo-Yo Intermittent Recovery Test (Yo-Yo IR1). This is an endurance test that gradually increases the running speed according to the signal tone coming from the signal device that starts with $10 \mathrm{~km}$ running speed in a $2 \times 20 \mathrm{~m}$ area. After every $40 \mathrm{~m}$ of running, there is an active recovery area of $2 \times 5 \mathrm{~m}$ for 10 seconds. The test was terminated when the person missed three beeps or when the athlete runs out (Krustrup et al., 2003:697-705).

Functional Movement Screen: The FMS consists of 7 movement tests and 3 control tests.

Movement Tests:
Deep squat, hurdle step, in-line lunge, shoulder mobility, active straight leg raise, trunk stability push up, rotary stability.

Clearing Tests:

Impingement clearing test, press-up clearing test, posterior rocking clearing test (Cook et al. 2014:396-409).

The athletes were scored 0-3, the highest score was recorded after 3 attempts.

The statistical analysis of the study was made with the SPSS 21.0 program, the independent t-test between groups, and the performance correlation with FMS scores was performed using Pearson's correlation analysis.

RESULTS

Table 1. Descriptive Characteristics of the Soccer Players, Average and Standard Deviations of Performance Tests, and FMS Scores

\begin{tabular}{lccc}
\hline Parameters & $\mathrm{n}$ & Mean & Standard Deviation \\
\hline Age (years) & 92 & 15.55 & 1.598 \\
\hline Height $(\mathrm{cm})$ & 92 & 171.18 & 17.66 \\
\hline Bodyweight $(\mathrm{kg})$ & 92 & 62.38 & 9.77 \\
\hline BMI $\left(\mathrm{kg} / \mathrm{m}^{2}\right)$ & 92 & 20.841 & 2.822 \\
\hline Long Jump $(\mathrm{cm})$ & 92 & 222.86 & 13.28 \\
\hline YO-YO $(\mathrm{m})$ & 81 & 1834.57 & 510.09 \\
\hline
\end{tabular}




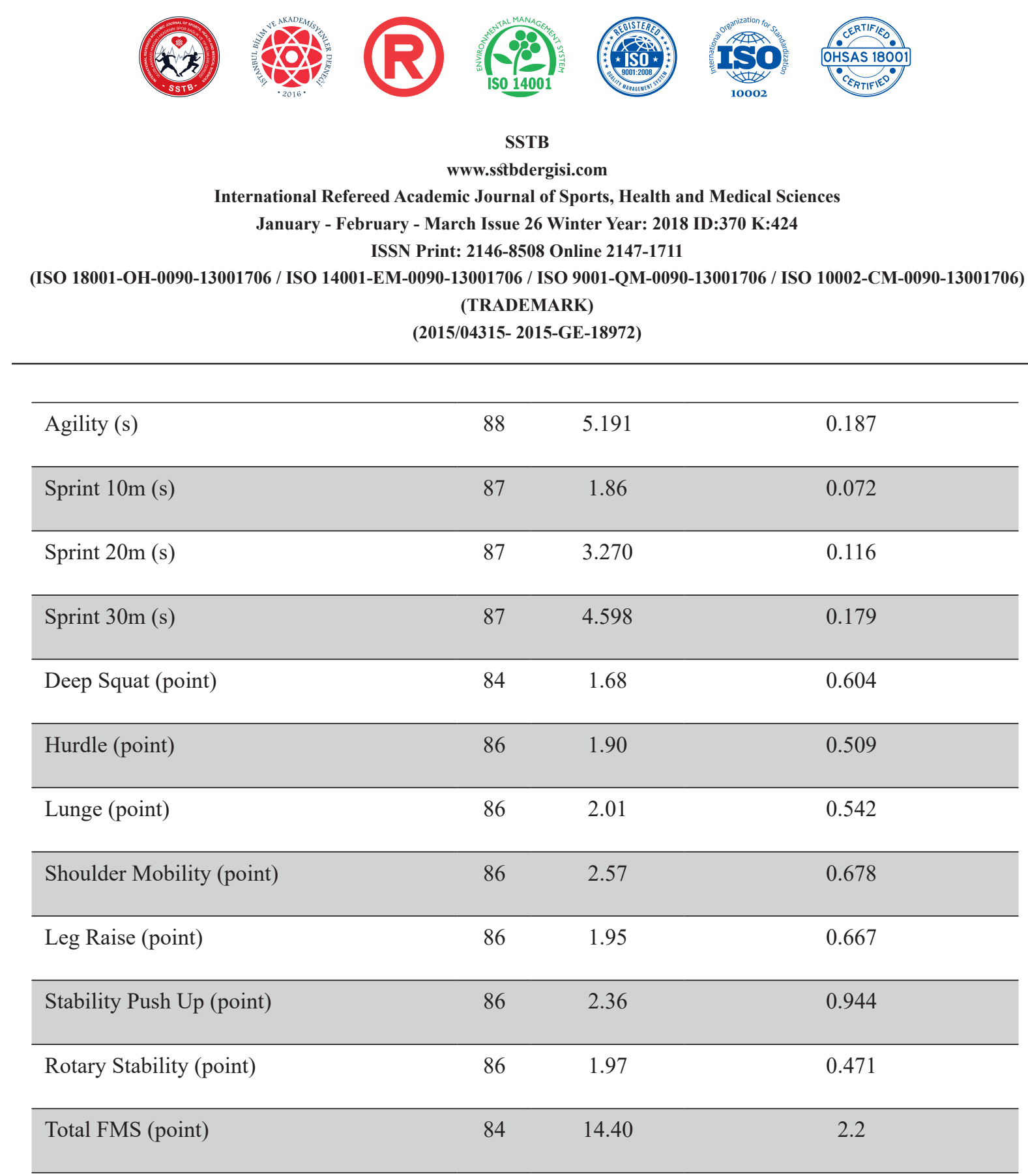

Table 1. shows the descriptive characteristics of the soccer players, the average and standard deviations of performance components, and FMS scores. The average long jump of the players was $222.86 \mathrm{~cm}$, the endurance average was $1834.57 \mathrm{~m}$, the average agility was $5.191 \mathrm{sec}$, and the average $10-\mathrm{m}, 20-\mathrm{m}$, and 30-m sprint was $1.86 \mathrm{sec}, 3.27 \mathrm{sec}, 4.59 \mathrm{sec}$, respectively. The average total FMS score of the soccer players was determined as 14.40.
When the FMS scores were examined, the average deep squat was 1.68 , the average hurdle step was 1.9 , the mean lunge was 2.01 , the average shoulder mobility was 2.57 , the average leg raise was 1.95 , the average push up was 2.36 , and the average stability was 1.97 . 


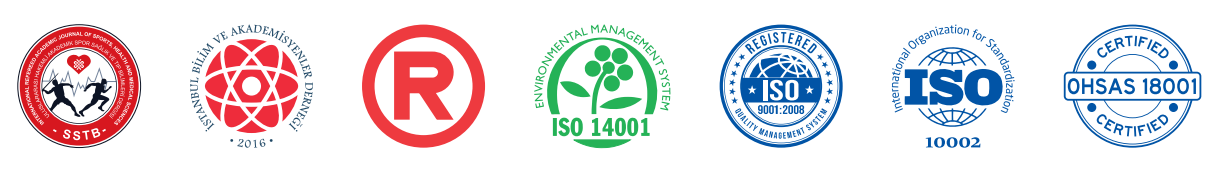

SSTB

www.sstbdergisi.com

International Refereed Academic Journal of Sports, Health and Medical Sciences

January - February - March Issue 26 Winter Year: 2018 ID:370 K:424

ISSN Print: 2146-8508 Online 2147-1711

(ISO 18001-OH-0090-13001706 / ISO 14001-EM-0090-13001706 / ISO 9001-QM-0090-13001706 / ISO 10002-CM-0090-13001706)

(TRADEMARK)

(2015/04315- 2015-GE-18972)

Table 2. Effect of Asymmetry on Performance in FMS Test

\begin{tabular}{|c|c|c|c|c|c|c|}
\hline Parameters & Asymmetry & $\mathrm{n}$ & Mean & Standard Deviation & $\mathrm{t}$ & $\mathrm{p}$ \\
\hline \multirow[t]{2}{*}{ Long Jump (cm) } & Yes & 57 & 220.86 & 12.98 & -1.867 & .065 \\
\hline & No & 35 & 226.11 & 13.31 & & \\
\hline \multirow[t]{2}{*}{ Yo-Yo (m) } & Yes & 55 & 1878.55 & 484.79 & 1.131 & .262 \\
\hline & No & 26 & 1741.54 & 558.31 & & \\
\hline \multirow[t]{2}{*}{ Agility (s) } & Yes & 54 & 5.181 & 0.189 & -0.579 & .564 \\
\hline & No & 34 & 5.21 & 0.186 & & \\
\hline \multirow[t]{2}{*}{ Sprint 10m (s) } & Yes & 54 & 1.86 & 0.071 & -0.803 & .424 \\
\hline & No & 33 & 1.87 & 0.074 & & \\
\hline \multirow[t]{2}{*}{ Sprint 20m (s) } & Yes & 54 & 3.26 & 0.112 & -0.623 & .535 \\
\hline & No & 33 & 3.28 & 0.123 & & \\
\hline \multirow[t]{2}{*}{ Sprint 30m (s) } & Yes & 54 & 4.59 & 0.174 & -0.466 & .643 \\
\hline & No & 33 & 4.61 & 0.188 & & \\
\hline
\end{tabular}

When the effect of asymmetry on performance was examined according to the FMS test in Table 2, it was seen that there was no significant effect of asymmetry $(p>.05)$.
When we examined for any asymmetry in the FMS test, we found that 57 (61.96\%) soccer players had asymmetry and 35 (38.04\%) had no asymmetry. 


\section{(20)
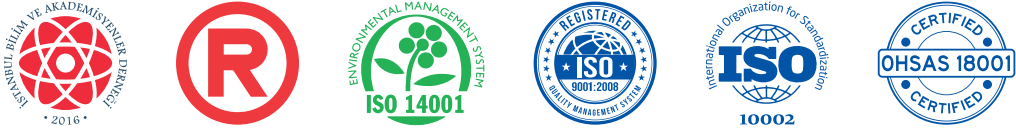

SSTB

www.sstbdergisi.com

International Refereed Academic Journal of Sports, Health and Medical Sciences

January - February - March Issue 26 Winter Year: 2018 ID:370 K:424

ISSN Print: 2146-8508 Online 2147-1711

(ISO 18001-OH-0090-13001706 / ISO 14001-EM-0090-13001706 / ISO 9001-QM-0090-13001706 / ISO 10002-CM-0090-13001706)

(TRADEMARK)

(2015/04315- 2015-GE-18972)

Table 3. Relationship Between Athlete's FMS Scores and Performance Parameters

\begin{tabular}{|c|c|c|c|c|c|c|c|}
\hline Parameters & & Long Jump & Endurance & Agility & Sprint $10 \mathrm{~m}$ & Sprint $20 \mathrm{~m}$ & Sprint $30 \mathrm{~m}$. \\
\hline \multirow[t]{2}{*}{ Deep Squat } & $\mathrm{r}$ & -.016 & .070 & -.103 & .091 & .078 & .087 \\
\hline & $\mathrm{p}$ & .885 & .542 & .365 & .426 & .499 & .447 \\
\hline \multirow[t]{2}{*}{ Hurdle Step } & $\mathrm{r}$ & .154 & -.047 & -.019 & .112 & .100 & .102 \\
\hline & $\mathrm{p}$ & .162 & .678 & .868 & .324 & .379 & .366 \\
\hline \multirow[t]{2}{*}{ In-Line Lunge } & $\mathrm{r}$ & -.003 & .069 & -.044 & -.032 & -.082 & -.068 \\
\hline & $\mathrm{p}$ & .976 & .542 & .696 & .776 & .472 & .549 \\
\hline \multirow[t]{2}{*}{ Shoulder Mobility } & $\mathrm{r}$ & -0.035 & -0.042 & 0.084 & 0.216 & 0.180 & 0.177 \\
\hline & $\mathrm{p}$ & .751 & .707 & .453 & .055 & .110 & .116 \\
\hline \multirow[t]{2}{*}{ Active Leg Raise } & $\mathrm{r}$ & 0.075 & $0.270^{*}$ & $-0.273^{*}$ & 0.146 & 0.123 & 0.081 \\
\hline & $\mathrm{p}$ & .500 & .015 & .014 & .197 & .277 & .477 \\
\hline \multirow[t]{2}{*}{ Stability Push Up } & $\mathrm{r}$ & -0.136 & -0.021 & 0.017 & -0.019 & -0.031 & 0.014 \\
\hline & $\mathrm{p}$ & .218 & .851 & .883 & .870 & .785 & .902 \\
\hline \multirow[t]{2}{*}{ Rotary Stability } & $\mathrm{r}$ & -0.050 & $0.259^{*}$ & 0.095 & 0.105 & 0.090 & 0.084 \\
\hline & $\mathrm{p}$ & .648 & .019 & .401 & .354 & .429 & .456 \\
\hline \multirow[t]{2}{*}{ FMS Total Score } & $\mathrm{r}$ & -0.013 & 0.125 & -0.074 & 0.167 & 0.131 & 0.145 \\
\hline & $\mathrm{p}$ & .904 & .273 & .516 & .143 & .253 & .205 \\
\hline
\end{tabular}




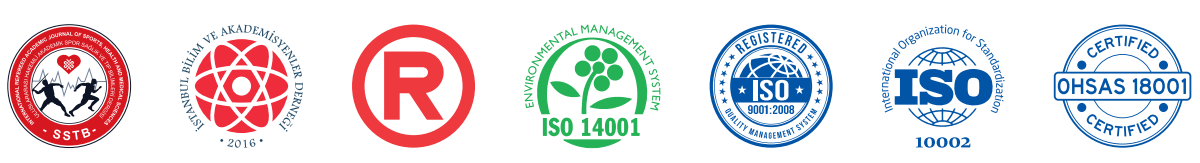

SSTB

www.sstbdergisi.com

International Refereed Academic Journal of Sports, Health and Medical Sciences

January - February - March Issue 26 Winter Year: 2018 ID:370 K:424

ISSN Print: 2146-8508 Online 2147-1711

(ISO 18001-OH-0090-13001706 / ISO 14001-EM-0090-13001706 / ISO 9001-QM-0090-13001706 / ISO 10002-CM-0090-13001706)

(TRADEMARK)

(2015/04315- 2015-GE-18972)

When the relationship between FMS scores and performance parameters of athletes was examined in Table 3, it was determined that there was a relation between the Yo-Yo test and active straight leg raise $(\mathrm{p}<.05)(\mathrm{r}=$ 0.270). The relationship between the Yo-Yo test and the rotary stability was also found as significant $(\mathrm{p}<.05)(\mathrm{r}=0.259)$.

The relationship between the agility test and active straight leg raise was found as significant $(\mathrm{p}<.05)(\mathrm{r}=-0.273)$. The other parameters seemed to be unrelated.

\section{DISCUSSION}

Although the result of a successful soccer match is mostly determined by the level of technique and tactics, the ability to move with high athletic performance contributes to elite performance (Mohr et al., 2008:341349). Soccer requires a high level of athletic performance for success (Stolen et al., 2005:501-536).

In our study, the average long jump of the players was $222.86 \mathrm{~cm}$, the average endurance was $1834.57 \mathrm{~m}$, the average agility was $5.191 \mathrm{sec}$, and the average 10-m, 20-m, and $30-\mathrm{m}$ sprints were $1.86 \mathrm{sec}, 3.27 \mathrm{sec}$, and 4.59 sec, respectively.

Soccer players usually run between 10 and 12 $\mathrm{km}$ during matches; $25 \%$ of this distance is walking, $37 \%$ is slow running, $20 \%$ is sub- maximal movements, $11 \%$ is sprint, and $7 \%$ is backward running. These data show that the aerobic energy system is used predominantly in soccer and that the anaerobic energy system is also used (Bangsbo et al., 2006:665674).

Physical changes associated with training cause different physical changes in each age group. It has been reported that the results of regular training in amateur and adolescent athletes lead to greater improvement than in high-level athletes (Ateş and Ateşoğlu., 2007:21).

Movements in soccer are performed with recovery in short periods of time (Mohr et al., 2005:593-599). It is necessary for soccer players to develop endurance in order to maintain performance during competition (Helgerud et al., 2001:1925-1931).

Elite 14-year-old soccer player's YO-YO IRT 1 durability test average was $2200 \mathrm{~m}$ (Bangsbo and Mohr, 2012:28). In our study, the results show that the soccer players we tested were below the elite level.

In the present study, 92 young soccer players were evaluated by scoring seven different movement patterns of FMS. The total FMS scores of the soccer players was determined as 14.40. When the FMS scores were examined, the average deep squat was 1.68 , the average hurdle step was 1.9 , the average in-line 


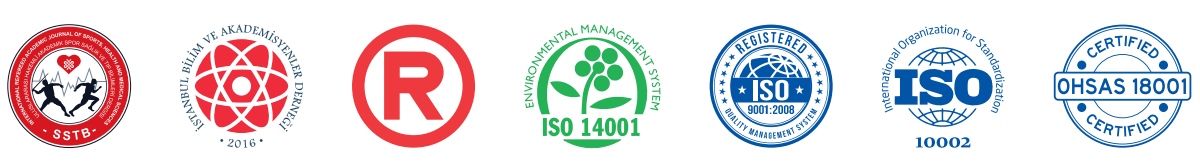

SSTB

www.sstbdergisi.com

International Refereed Academic Journal of Sports, Health and Medical Sciences

January - February - March Issue 26 Winter Year: 2018 ID:370 K:424

ISSN Print: 2146-8508 Online 2147-1711

(ISO 18001-OH-0090-13001706 / ISO 14001-EM-0090-13001706 / ISO 9001-QM-0090-13001706 / ISO 10002-CM-0090-13001706)

(TRADEMARK)

(2015/04315- 2015-GE-18972)

lunge was 2.01, the average shoulder mobility was 2.57 , the average active straight leg raise was 1.95 , the average stability push up was 2.36 , and the average of the rotary stability was 1.97 .

When the asymmetry effect according to the FMS test was examined, it was seen that there was no significant effect of asymmetry ( $p>$ $.05)$.

When any asymmetry score was examined in the FMS test, 57 (61.96\%) soccer players had asymmetry and 35 (38.04\%) had no asymmetry.

If any FMS movement score is below 2 points, or if the total score is below 14 points, or if right and left body asymmetry occurs, the injury risk rate increases (Chorba, 2010:47-54). In our study group, the percentage of athletes with at least one asymmetry was $61 \%$, and the total FMS scores of the athletes were 14 and above, which was sufficient for the movement screening score. Our athletes' average deep squat, hurdle step, active straight leg raise, and rotary stability patterns were below 2 points. This indicates that the risk of injury is high.

When the relationship between the FMS scores and the performance parameters of the athletes was examined, it was found that there was a relationship between the YO-YO test and active straight leg raise $(\mathrm{p}<.05)(\mathrm{r}=$
0.270 ), YO-YO test, and rotary stability ( $\mathrm{p}<$ $.05)(\mathrm{r}=0.259)$.

A significant relationship was found between the agility test and active straight leg raise $(\mathrm{p}<.05)(\mathrm{r}=-0.273)$. The other parameters seemed to be unrelated.

Studies that suggested that functional movement screening was not related to athletic performance (Parchmann et al., 2011:33783384) are contrary to our findings. In our study, although not all the performance parameters were related to the motion analysis, it was found that endurance and agility were related to the movement analysis.

\section{REFERENCES}

AGRESTA, C., SLOBODINSKY, M., TUCKER, C., (2014). Functional Movement Screen - Normative Values in Healthy Distance Runners. Int J Sports Med, 35(14):1203-1207

ATEŞ, M., ATEŞOĞLU, U., (2007). Pliometrik Antrenmanın 16-18 Yaş Grubu Erkek Futbolcuların Üst ve Alt Ekstremite Kuvvet Parametreleri Üzerine Etkisi. Spormetre Beden Eğitimi ve Spor Bilimleri Dergisi, (1): 21-28

BANGSBO, J., MOHR, M., (2012). Fitness Testing in Football. Bangsbosport, ss.27 


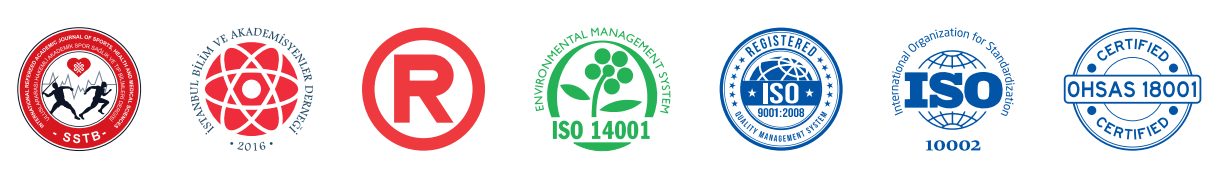

SSTB

www.sstbdergisi.com

International Refereed Academic Journal of Sports, Health and Medical Sciences

January - February - March Issue 26 Winter Year: 2018 ID:370 K:424

ISSN Print: 2146-8508 Online 2147-1711

(ISO 18001-OH-0090-13001706 / ISO 14001-EM-0090-13001706 / ISO 9001-QM-0090-13001706 / ISO 10002-CM-0090-13001706) (TRADEMARK)

(2015/04315- 2015-GE-18972)

BANGSBO, J., MOHR, M., KRUSTRUP, P., (2006). Physical and Metabolic Demands of Training and Match-Play in The Elite Football Player. Journal of sports sciences, 24(07): 665-674.

\section{BARDENETT, S.M., MICCA, J.J., DENOY-} ELLES, J.T., MILLER, S.D., JENK, D.T., BROOKS, G.S., (2015). Functional Movement Screen Normative Values and Validity in High School Athletes: Can The FMS ${ }^{\mathrm{TM}}$ Be Used as A Predictor of Injury? Int J Sports Phys Ther, 10(3):303308

\section{BODDEN, J.G., NEEDHAM, R.A.,} CHOCKALINGAM, N., (2015). The Effect of an Intervention Program on Functional Movement Screen Test Scores in Mixed Martial Arts Athletes. The Journal of Strength and Conditioning Research, 29(1): 219-225

CHORBA, R.S., CHORBA, D.J., BOUILLON, L.E, OVERMYER, C.A., LANDIS, J.A., (2010). Use of a Functional Movement Screening Tool to Determine Injury Risk in Female Collegiate Athletes. N Am J Sports Phys Ther, 5(2): 4754

COOK, G., BURTON, L., HOOGENBOOM, B.J., VOIGGHT, M., (2014). Functional Movement Screening: The Use of Fundamental Movements as An Assessment of
Function - Part 1. Int J Sports Phys Ther. 9(3):396-409

ENOKSEN, E., TONNESSEN, E., SHALFAWI, S., (2009). Validity and Reliability of the Newtest Powertimer 300-Series Testing System. Journal of Sports Sciences, 26(4): 77-84

HARMAN, E., GARHAMMER, J., (2008). Administration, Scoring and Interpretation of Selected Tests. In: Baechle Tr, Earle R. W., Eds. Essentials of Strength and Conditioning. Champaign, Il: Human Kinetics, ss. 249-292

HELGERUD, J., ENGEN, L.C., WISLOFF, U, AND HOFF, J., (2001). Aerobic Endurance Training Improves Soccer Performance. Med Sci Sports Exerc 33: 1925-1931

KAZMAN, J.B., GALECKI, J.M., LISMAN, P., DEUSTER, P.A., O'CONNOR, F.G., (2014). Factor Structure of the Functional Movement Screen in Marine Officer Candidates. Journal of Strength and Conditioning Research, 28: 672-678

KIESEL, K., PLISKY, P.J., VOIGHT, M.L., (2007). Can Serious Injury in Professional Football Be Predicted by A Preseason Functional Movement Screen? N Am J Sports Phys Ther. 2(3):147-158 

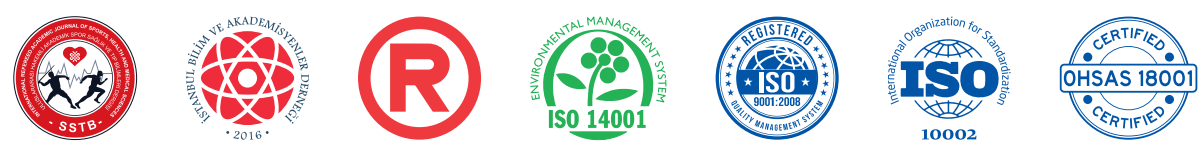

SSTB

www.sstbdergisi.com

International Refereed Academic Journal of Sports, Health and Medical Sciences

January - February - March Issue 26 Winter Year: 2018 ID:370 K:424

ISSN Print: 2146-8508 Online 2147-1711

(ISO 18001-OH-0090-13001706 / ISO 14001-EM-0090-13001706 / ISO 9001-QM-0090-13001706 / ISO 10002-CM-0090-13001706) (TRADEMARK)

(2015/04315- 2015-GE-18972)

KRUSTRUP, P., MOHR, M., AMSTRUP, T., RYSGAARD, T., JOHANSEN, J., STEENSBERG, A., BANGSBO, J., (2003). The Yo-Yo Intermittent Recovery Test: Physiological Response, Reliability, and Validity. Medicine and Science in Sports and Exercise, 35(4): 697-705

LI, Y., WANG, X., CHEN, X., DAI, B., (2015). Exploratory Factor Analysis of the Functional Movement Screen in Elite Athletes. J Sports Sci. 33(11):1166-1172

LOUDON, J.K., PARKERSONMITCHELL, A.J., HILDEBRAND, L.D., TEAGUE, C., (2014). Functional Movement Screen Scores in a Group of Running Athletes. Journal of Strength and Conditioning Research, 28: 909-913

MARQUES, V.B., MEDEIROS, T.M., DE SOUZA STIGGER, F., NAKAMURA, F.Y, BARONI, B.M, (2017). The Functional Movement Screen $\left(\mathrm{FMS}^{\mathrm{TM}}\right)$ in Elite Young Soccer Players Between 14 And 20 Years: Composite Score, Individual-Test Scores and Asymmetries. Int $\mathbf{J}$ Sports Phys Ther. 12(6):977-985

MEEUWISSE, W.H., FOWLER. P.J., (1988), Frequency and Predictability of Sports Injuries in Intercollegiate Athletes. Can J Sport Sci., 13(1):35-42
METZL, J.D., (2000). The Adolescent PreParticipation Physical Examination: is it Helpful? Clin Sports Med, 19(4):577-592

MOHR, M., KRUSTRUP, P., AND BANGS$B O, J .$, (2005). Fatigue in Soccer: A Brief Review. J Sport Sci, 23: 593-599

MOHR, M., KRUSTRUP, P., ANDERSSON, H., KIRKENDAL, D., AND BANGSBO, J., (2008). Match Activities of Elite Women Soccer Players at Different Performance Levels. J Strength Cond Res, 22: $341-349$

MOKHA, M., SPRAGUE, P.A., GATENS, D.R., (2016). Predicting Musculoskeletal Injury in National Collegiate Athletic Association Division Il Athletes From Asymmetries and Individual-Test Versus Composite Functional Movement Screen Scores. J Athl Train, 51(4):276-282

MORAN, R.W., SCHNEIDERS, A.G, MAJOR, K.M., SULLIVAN, S.J., (2016). How Reliable are Functional Movement Screening Scores. A Systematic Review of Rater Reliability. Br J Sports Med, 50(9):527-536

PARCHMANN, C.J., MCBRIDE, J. M., (2011). Relationship Between Functional Movement Screen and Athletic Performance. The Journal of Strength and Conditioning Research, 25(12): 3378-3384 

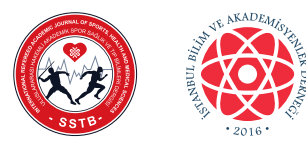

SSTB

www.sstbdergisi.com

International Refereed Academic Journal of Sports, Health and Medical Sciences

January - February - March Issue 26 Winter Year: 2018 ID:370 K:424

ISSN Print: 2146-8508 Online 2147-1711

(ISO 18001-OH-0090-13001706 / ISO 14001-EM-0090-13001706 / ISO 9001-QM-0090-13001706 / ISO 10002-CM-0090-13001706) (TRADEMARK)

(2015/04315- 2015-GE-18972)

PARENTEAU-G, E., GAUDREAULT, N., CHAMBERS, S., BOISVERT, C., GRENIER, A., GAGNE, G., BALG, F., (2014). Functional Movement Screen Test: a Reliable Screening Test for Young Elite Ice Hockey Players. Physical Therapy in Sport, 15: 169-175

REIMAN, R.P., MANSKE, R.C., (2009). Functional Testing in Human Performance. Human Kinetics, ss. 193-201

SCHNEIDERS, A.G., DAVIDSSON, A., HORMAN, E., SULLIVAN, S.J., (2011). Functional Movement Screen Normative Values in A Young, Active Population. International Journal of Sports Physical Therapy, (6): 75-82
STOLEN, T.., CHAMARI, K., CASTAGNA, C., AND WISLOFF, U., (2005). Physiology of Soccer: An Update. Sports Med, 35: $501-536$

TEYHEN, D.S., RIEBEL, M.A., MCARTHUR, D.R., SAVINI, M., JONES, M.J., GOFFAR, S.L., PLISKY, P.J., (2014). Normative Data and The Influence of Age and Gender on Power, Balance, Flexibility, and Functional Movement in Healthy Service Members. Military Medicine, 179(4): 413-420

WARREN, M., SMITH, C.A., CHIMERA, N.J., (2015). Association of The Functional Movement Screen with Injuries in Division I Athletes. Journal of Sport Rehabilitation, 24(2): 163-170 